\title{
Facilitation of the Estuary/Ocean
} Subgroup

for Research, Monitoring, and

Evaluation,

FYo7 Annual Report

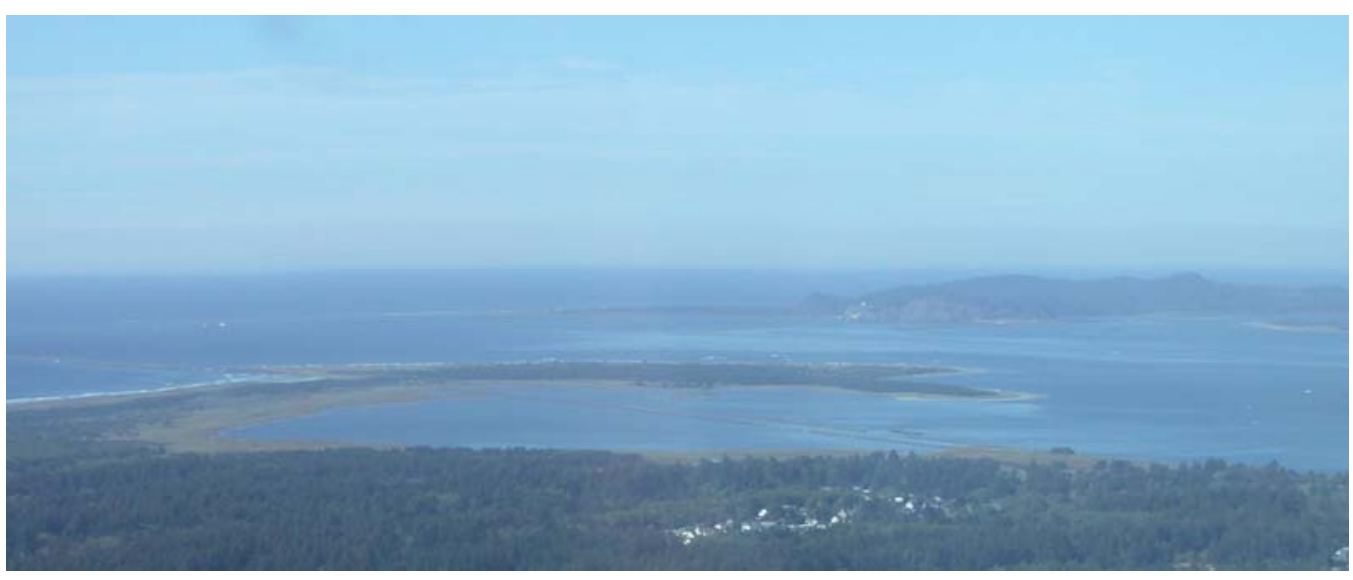

October 10, 2007

Prepared for the Bonneville Power Administration

Under a Related Services Agreement with the U.S. Department of Energy

Contract DE-AC05-76RLO1830

Pacific Northwest

National Laboratory

Operated by Battelle for the

U.S. Department of Energy
Bonneville

Power Administration 


\section{DISCLAIMER}

This report was prepared as an account of work sponsored by an agency of the United States Government. Neither the United States Government nor any agency thereof, nor Battelle Memorial Institute, nor any of their employees, makes any warranty, express or implied, or assumes any legal liability or responsibility for the accuracy, completeness, or usefulness of any information, apparatus, product, or process disclosed, or represents that its use would not infringe privately owned rights. Reference herein to any specific commercial product, process, or service by trade name, trademark, manufacturer, or otherwise does not necessarily constitute or imply its endorsement, recommendation, or favoring by the United States Government or any agency thereof, or Battelle Memorial Institute. The views and opinions of authors expressed herein do not necessarily state or reflect those of the United States Government or any agency thereof.

PACIFIC NORTHWEST NATIONAL LABORATORY

operated by BATTELLE for the

UNITED STATES DEPARTMENT OF ENERGY

under Contract DE-AC05-76RL01830

Cover Photo (by G. Johnson): View of the Mouth of the Columbia River with Trestle Bay in the foreground and the Pacific Ocean in the background. 


\section{Facilitation of the Estuary/Ocean Subgroup \\ for Research, Monitoring, and Evaluation - FYo7 Annual Report}

Gary E. Johnson

Heida L. Diefenderfer

October 10, 2007

Prepared for the Bonneville Power Administration Under a Related Services Agreement with the U.S. Department of Energy

Contract DE-AC05-76RLO1830

Pacific Northwest National Laboratory

Marine Sciences Laboratory

Sequim, Washington 98382 



\section{Abstract}

This annual report is a deliverable for fiscal year 2007 (FY07) for Project 2002-077-00, Facilitation of the Estuary/Ocean Subgroup (EOS). The EOS is part of the research, monitoring, and evaluation (RME) effort of the Action Agencies (Bonneville Power Administration, U.S. Army Corps of Engineers, U.S. Bureau of Reclamation) developed in response to responsibilities arising from the Endangered Species Act as a result of operation of the Federal Columbia River Power System (FCRPS). The goal of the EOS project is to facilitate activities of the estuary/ocean RME subgroup as it coordinates design and implementation of federal RME in the lower Columbia River and estuary. In FY07, EOS project accomplishments included 1) subgroup meetings; 2) participation in the estuary work group of the Pacific Northwest Aquatic Monitoring Partnership; 3) project management via the project tracking system, PISCES; 4) quarterly project status reports; and 5) a major revision to the Estuary RME Plan (new version September 2007) based on comments by EOS members and invited reviewers. 


\section{Preface}

The Bonneville Power Administration (BPA) contracted with the Pacific Northwest National Laboratory (PNNL) to coordinate and facilitate workings of the Estuary/Ocean Subgroup (BPA Project No. 2002-077-00; Contract No. 26934, release 3). Initiated in 2002, the EOS is composed of members from Bonneville Power Administration (BPA), the U.S. Army Corps of Engineers (USACE), the Lower Columbia River Estuary Partnership (LCREP), the National Oceanic and Atmospheric Administration National Marine Fisheries Service (NOAA Fisheries), and PNNL's Marine Sciences Laboratory. It is one of multiple work groups in the federal RME effort developed in response to responsibilities arising from the Endangered Species Act as a result of operation of the FCRPS. The estuary/ocean subgroup is tasked by NOAA Fisheries and the Action Agencies to design and coordinate implementation of the federal RME plan for the lower Columbia River and estuary, including the plume. The purpose of project 2002-077-00 is to coordinate and facilitate activities of the EOS. For more information about the EOS, please contact Gary Johnson (503-4177567).

\section{Acknowledgments}

Important contributions to this project were made by Blaine Ebberts and Doug Putman (Portland District, USACE), Eric Braun (North Pacific Division, USACE), Cathy Tortorici (NOAA Fisheries), Jim Geiselman and Tracey Yerxa (BPA), Scott McEwen and Jill Leary (Estuary Partnership), Charlie Paulsen (Paulsen Environmental Research, Inc.), Al Giorgi and Tracey Hillman (BioAnalysts, Inc.), John Skalski (University of Washington), and Terri Gilbride, Jan Slater, and Ron Thom (PNNL). 


\section{Acronyms}

AA - Action Agencies

AFEP - Anadromous Fish Evaluation Program

$\mathrm{BiOp}$ - Biological Opinion

BOR - Bureau of Reclamation

BPA - Bonneville Power Administration

CREDDP - Columbia River Estuary Data Development Program

CREST - Columbia River Estuary Study Taskforce

CSMEP - Collaborative Systemwide Monitoring and Evaluation Project

EORME Proposed Action - Estuary and Ocean Research, Monitoring and Evaluation Proposed Action

EOS - Estuary/Ocean Subgroup

ERME - Estuary research, monitoring, and evaluation

ESA - Endangered Species Act

ESU -- evolutionarily significant unit

FCRPS - Federal Columbia River Power System

FY07 - Fiscal Year 2007

ISRP - Independent Scientific Review Panel

LCFRB - Lower Columbia Fish Recovery Board

LCREP - Lower Columbia River Estuary Partnership

LTER - Long Term Ecosystem Research

MRE - Monitoring, Research, and Evaluation effort led by the Lower Columbia Fish Recovery Board

NED - Northwest Environmental Data network

NOAA - National Oceanic and Atmospheric Administration

NOAA Fisheries - NOAA National Marine Fisheries Service

NPCC - Northwest Power and Conservation Council

ODEQ - Oregon Department of Environmental Quality

PA - Proposed Action

PER - Paulsen Environmental Research

PISCES - the name for the BPA project tracking system

PNAMP - Pacific Northwest Aquatic Monitoring Partnership

PNNL - Pacific Northwest National Laboratory

PSMFC - Pacific States Marine Fisheries Commission 
RIMS - Regional Information Management Strategy

$\mathrm{RME}$ - research, monitoring, and evaluation

UPA - Updated Proposed Action

USACOE - US Army Corps of Engineers

USGS - U.S. Geological Survey

UW - University of Washington 


\section{Table of Contents}

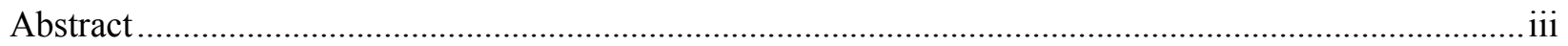

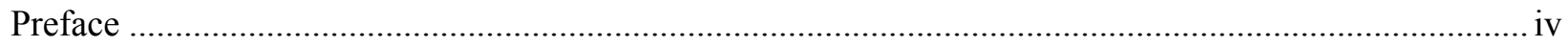

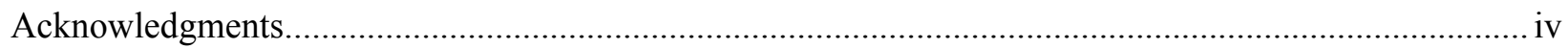

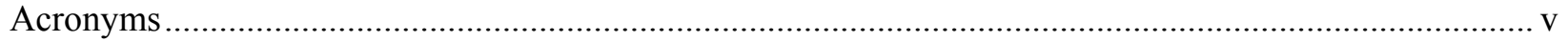

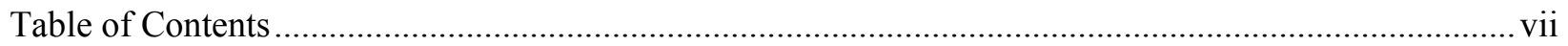

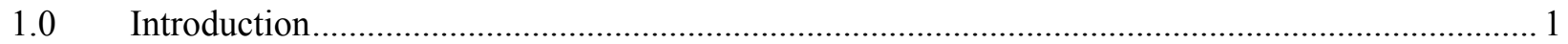

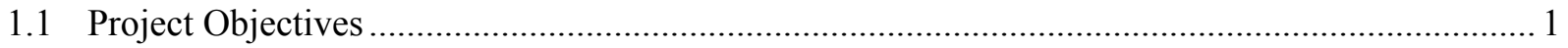

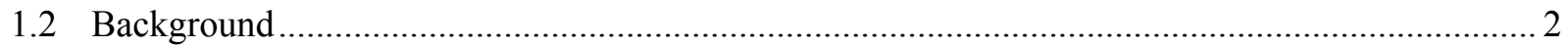

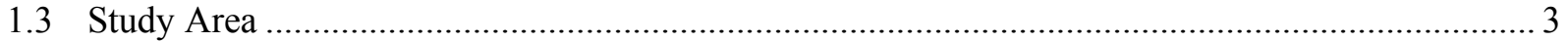

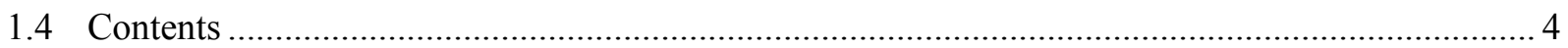

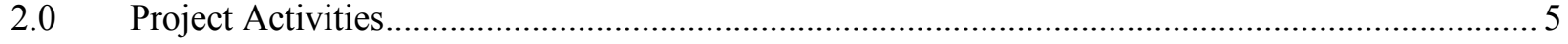

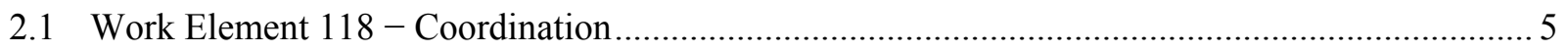

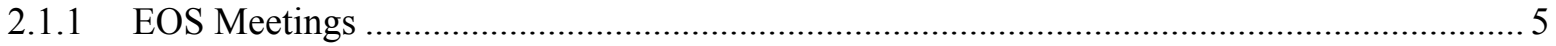

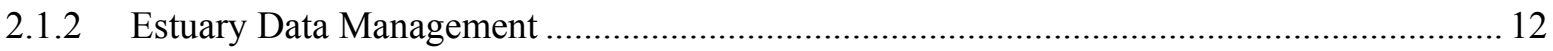

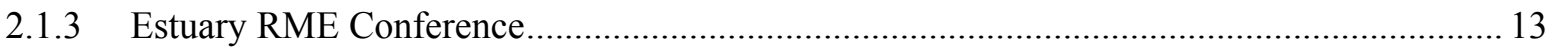

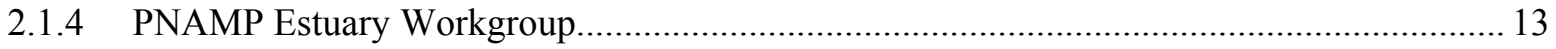

2.2 Work Element 119 - Manage and Administer Project ............................................................ 13

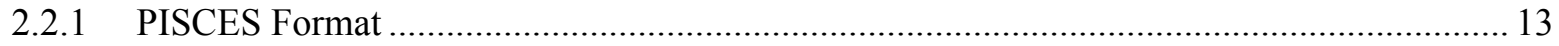

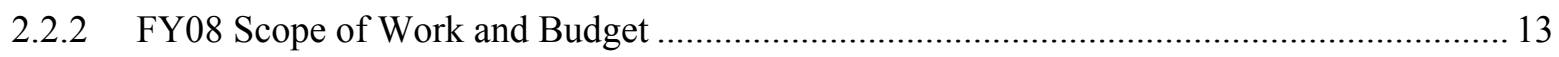

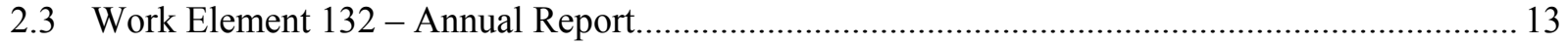

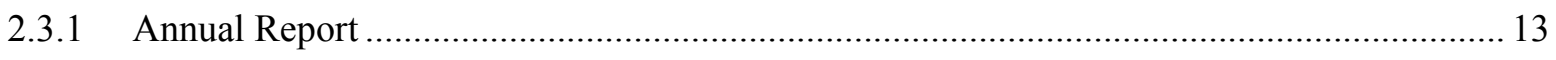

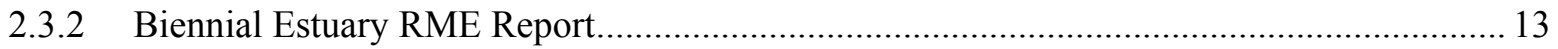

2.4 Work Element 141 - Status Reports …….......................................................................... 15

2.5 Work Element 174 - Produce Plan ....................................................................................... 15

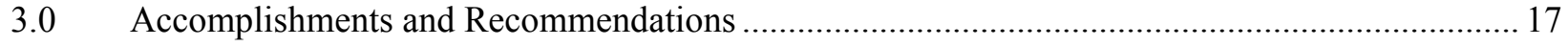

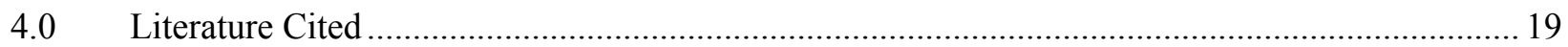




\subsection{Introduction}

This document is the annual report for fiscal year 2007 (FY07) for Project 2002-077-00, Facilitation of the Estuary/Ocean Subgroup (EOS). The EOS is part of the research, monitoring, and evaluation (RME) effort developed by the Action Agencies (Bonneville Power Administration, U.S. Army Corps of Engineers, U.S. Bureau of Reclamation) in response to obligations arising from the Endangered Species Act as a result of operation of the Federal Columbia River Power System (FCRPS). For the purposes of this report, the Columbia River estuary includes mainstem waters from Bonneville Dam down through the lower river and estuary into the ocean plume (Figure 1).

The goal of this project was to facilitate activities of the estuary/ocean RME subgroup (EOS) as it coordinated implementation of the estuary RME plan in FY07 with the Pacific Northwest Aquatic Monitoring Partnership's (PNAMP) estuary workgroup, the Northwest Power and Conservation Council's (NPCC) Fish and Wildlife Program, federal RME parties, and other federal and non-federal entities conducting RME in the estuary.

\subsection{Project Objectives}

The EOS project had the following objectives for FY07, designated by numbered categories in the PISCES project tracking system:

118 Coordination - Continue facilitation of the estuary/ocean RME subgroup, including coordination with the following entities:

a) RME Technical/Policy Oversight Group and Federal Caucus - attend meetings and provide updates as required;

b) RME Data Management Subgroup - coordinate the estuary RME work with the developing data management effort for the basin-wide RME;

c) NPCC and Updated Proposed Action (UPA) - Convene biennial estuary RME workshops to present new data, evaluate the conduct of the estuary RME program, exchange information, and provide input to the estuary/ocean RME subgroup.

d) PNAMP estuary workgroup - attend and participate in workgroup meetings and assist in the development of coordinated estuary planning and monitoring approaches within PNAMP.

119 Project Management - Manage and administer the project according to BPA's "Work

Element/Milestone" based project management and reporting system (PISCES).

132 Annual Report - Produce an annual report of project activities, including a detailed outline for a biennial estuary RME summary report incorporating adaptive management recommendations at the program level for submittal to the Action Agencies, estuary restoration project leaders, and other related entities (e.g., subbasin plan implementers, PNAMP). 


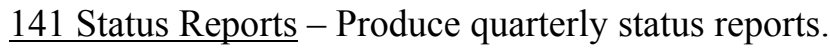

174 Plan - Revise the estuary-RME plan (dated May 2006) as new information becomes available concerning RME in the lower Columbia River and estuary, including the plume.

\subsection{Background}

The function of the Columbia River estuary ${ }^{1}$ in the life history of threatened and endangered salmonids is more than simply serving as a corridor for passage between the tributaries and the Pacific Ocean. The estuary provides habitat for multiple life history stages of salmon and steelhead, ranging from the rearing and feeding of fry, fingerlings, and smolts to the passage upstream of adults (Bottom et al. 2005). Usage of estuary habitat by juvenile salmonids varies by species and life history stage (Rich 1920).

Generally, the closer the natal

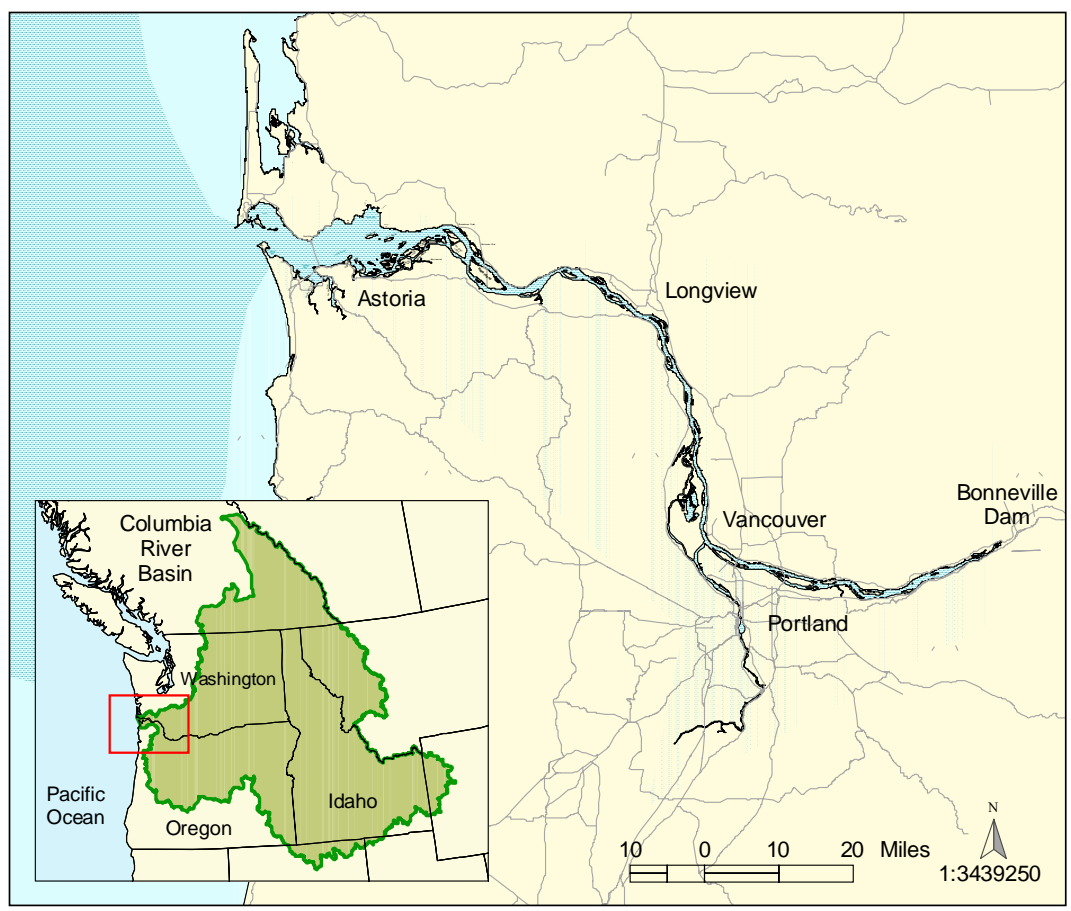
stream is to the estuary and the smaller the juvenile migrant, the more likely it is that juveniles will use estuarine habitats as feeding, rearing and refuge areas, i.e., as more than just a migration corridor. Information on salmon biology and ecology in the Columbia River estuary can be found in Bottom et al. 1984, 2005; Dawley et al. 1985a,b, 1986; Durkin et al. 1981; Kirn et al. 1986; Ledgerwood et al. 1991; McCabe et al. 1983, 1986; McConnell et al. 1983; and Reimers and Loeffel 1967. In recognition of the estuary's importance to salmon population viability, the 2000 and 2004 Biological Opinions (BiOp) on operation of the Federal Columbia River Power System called for the restoration of estuarine habitat as a pivotal action to avoid jeopardizing the continued existence of listed salmonid populations (NOAA Fisheries 2000; 2004), as well as comprehensive research, monitoring, and evaluation for listed salmon. Recognition of the estuary's importance has continued during the ongoing BiOp remand process (2005 to present).

${ }^{1}$ The Columbia River estuary is defined as the tidally influenced portion of the river from Bonneville Dam to the plume. This is consistent with Bottom et al. (2005) and the Lower Columbia River Estuary Program (1999). Lower Columbia River tributaries are not part of the estuary RME study area. 
Recognition of the estuary's importance has continued during the ongoing BiOp remand process (2005 to present). NOAA Fisheries and the Action Agencies established a process to develop a basinwide RME plan that fulfills Action Items in the 2000 BiOp's Reasonable and Prudent Alternatives and satisfies the Federal Columbia River Salmon Recovery Strategy (www.salmonrecovery.gov). The federal RME process involves a Policy Oversight Group and six technical subgroups: Status Monitoring, Effectiveness Research, Hydrosystem, Hatchery/Harvest, Data Management, and Estuary/Ocean (EOS). One outcome of the federal RME process was a draft Basin-wide RME Plan (Jordan et al. 2003). In FY07, however, federal RME occurred in the context of ongoing litigation on the legal standing of the Biological Opinions that originally created the RME process. Because of uncertainty in the outcome of the litigation, federal RME was instituted carefully with emphasis on expanded coordination with the states and tribes and other regional monitoring efforts.

For example, FY07 saw continued integration of federal BiOp RME efforts with the Pacific Northwest Aquatic Monitoring Partnership (PNAMP). PNAMP is an assemblage of federal, state, and tribal agencies whose goal is "...to coordinate important scientific information at the appropriate scales needed to inform public policy and resource management decisions” (PNAMP 2004). PNAMP's geographic scope includes the Pacific Northwest and northern California. Most of their efforts to date have involved tributary habitats, although in FY05 PNAMP coordination work extended into estuarine habitats, including the Columbia River estuary; this coordination continued in FY06 and FY07.

Overall in FY07, estuary/ocean subgroup RME activities progressed in conjunction with coordination and revision of the federal Estuary RME Plan (Johnson et al. 2007). The document herein is the annual report of activities and accomplishments for the EOS project 2002-077-00 in FY07. Previous annual reports were submitted for FY05 and FY06 (Johnson 2005; 2006)

\subsection{Study Area}

A number of publications provide descriptive information about the Columbia River estuary:

- the Salmon at River's End report by Bottom et al. (2005);

- Fresh et al.'s (2004) Role of the Estuary in the Recovery of Columbia River Basin Salmon and Steelhead;

- the Biological Assessment for the Columbia River Channel Improvements Project by the U.S. Army Corps of Engineers (2001);

- the RPA Action 158 action plan by Berquam et al. (2003) and the RPA Action 159 habitat restoration report by Johnson et al. (2003);

- the Northwest Power and Conservation Council's (NPCC) subbasin plan for the estuary (Lower Columbia River Estuary Partnership and Lower Columbia Fish Recovery Board 2004a; 2004b).

Important earlier compendiums include: 
- The Columbia River Estuary and Adjacent Ocean Waters by Pruter and Alverson (1972);

- "Columbia River Estuary" in Changes in Fluxes in Estuaries: Implications from Science to Management by Dyer and Orth (1994);

- Columbia River: Estuarine System by Small (1990), which contains reviews of earlier work supported by the Columbia River Estuary Data Development Program (CREDDP) on physical and biological processes (CREDDP 1984a, 1984b).

Another comprehensive environmental study of the lower Columbia River was the Bi-State Water Quality Study (TetraTech 1996; Fuhrer et al. 1996), completed as part of the process to include the Columbia River estuary in the U.S. Environmental Protection Agency's National Estuary Program.

\subsection{Contents}

This FY07 annual report for the EOS project has five sections: Introduction, Project Activities, Summary of Accomplishments, Recommendations for FY08, and Literature Cited. The Activities and Accomplishments sections are organized by the work elements listed in the objectives (Section 1.1). In sum, the FY07 EOS project resulted in expanded, substantive coordination with other regional RME forums, project tracking infrastructure, and a new version of the federal Estuary RME Plan. 


\subsection{Project Activities}

\subsection{Work Element 118 - Coordination}

\subsubsection{EOS Meetings}

The EOS met three times in FY07: November 30, 2006 and April 12 and July 11, 2007. The following section provides a condensed summary of key discussions that occurred during the EOS meetings. This material is based on notes intended submitted to EOS members after each meeting.

\subsubsection{Meeting Highlights - November 30, 2006}

Highlights of the meeting November 30, 2006 follow. The participants were: Blaine Ebberts (USACE), Gary Johnson (PNNL), Charlie Paulsen (Paulsen Environmental Research), Cathy Tortorici (NOAA Fisheries), Scott McEwen and Jill Leary (Estuary Partnership), and Jim Geiselman, Tracey Yerxa, and Ben Zelinsky (BPA). The meeting's objectives were to: (1) Receive and discuss updates on federal RME for the new BiOp, the Pacific Northwest Aquatic Monitoring Partnership (PNAMP), data management, and the Anadromous Fish Evaluation Program (AFEP) 2007; (2) Discuss the ongoing Estuary RME document; (3) Discuss three particular estuary RME projects proposed in the FY07-09 BPA/Northwest Power and Conservation Council's (NPCC) Fish and Wildlife (F\&W) Program.

\section{Updates (11/30/06)}

Federal RME. Geiselman reported that the ongoing Collaboration effort was using the Federal RME Framework as they design an RME program to cover BiOp needs, as well as Recovery needs. The RME subject areas for the Collaboration include hydrosystem, estuary, tributary habitat, harvest, predation, and invasive species. The process calls for the Action Agencies (BPA, Corps, and Bureau of Reclamation $[\mathrm{BOR}])$ to prepare a Proposed Action within a Biological Assessment. The Proposed Action is due at the end of January 2007. Johnson described the technical support separate from EOS that he has been providing to BPA on the estuary RME segment. Ebberts said that the Portland District needed to be in the loop on estuary RME. Ebberts also wondered if funding sources and amounts were being considered for estuary RME. Yerxa replied that BPA was working to develop funding options. This brought up the topic of in lieu funding by BPA - these are funds BPA spends on things that are the responsibility of other agencies. Geiselman said BPA will be much more sensitive to in lieu funding in the next BiOp than they were previously. Tortorici pointed out that NOAA Fisheries had given BPA feedback on the in lieu issue. Geiselman gave the heads-up that the Action Agencies (AA) intend to revise the Grand RME Plan (September 2003) and release a new version in 2007.

PNAMP. Tortorici reported that the inventory of RME programs/projects in the Pacific Northwest and Northern California the PNAMP Estuary Group started had been subsumed by the broad RME inventory within PNAMP. A contract has been let to the Pacific States Marine Fisheries Commission (PSMFC) to do the broad inventory. Geiselman said the intent is to "institutionalize" the inventory. 
Leary asked if anyone was able to use the inventory yet and the answer was it was still being populated. Geiselman noted two other PNAMP work products under development that are relevant to the estuary: a Monitoring Protocol Manager and a Data Dictionary. (These documents are apparently not yet available on the website www.pnamp.org.) Ebberts asked if the monitoring protocols included draft Estuary Restoration Monitoring Protocols Manual (Roegner et al. 2006) and the answer was probably not. Michael Newsom (BOR) is the lead on the monitoring protocols for PNAMP - Ebberts will send him the Estuary Protocols Manual. Also, Tortorici will inform Bayer (PNAMP Coordinator) about the manual at the next PNAMP Steering Committee meeting. Geiselman asked if the Estuary Protocols Manual was published - it is in a technical report. Tortorici mentioned the Nature Conservancy was working on a coast-wide monitoring protocols document.

Data Management. Johnson noted that Diefenderfer wanted the EOS to be aware of the Long-Term Ecosystem Research (LTER) program and that she'll talk more about this at a future EOS meeting. The LTER concept is something the EOS and grand federal RME should consider. Geiselman reported the NED/PNAMP and StreamNet data management proposals are on the agenda for the Council's meeting in December 2006. BPA intends to facilitate a regional data management strategy (RIMS, Regional Information Management Strategy) within the Proposed Action and identify at least what BPA will commit to. There's been a lot of discussion in NED on a pilot study for a data center. They may also build on the data needs arising from the intensively monitored watersheds in the John Day, Wenatchee, and Salmon river basins. BPA et al. are trying to build a broad strategy for data.

AFEP 2007. Ebberts noted that the Portland District is funding four estuary projects within its Anadromous Fish Evaluation Program (AFEP). 1) Bottom et al. Estuary Monitoring of Juvenile Salmonids. This will be the final year of data collection. Want to do peer-reviewed publications. 2) Muir et al. Ocean Entry Conditions. No more juvenile tagging is being undertaken. They are waiting for adult returns now and will correlate adult returns with conditions at ocean entry for juveniles. 3) Thom et al. Cumulative Effects of Multiple Restoration Projects. This project is ongoing. Field sites for 2007 are yet to be determined but likely will include some monitoring at the previous sites (Vera and Kandoll) and new monitoring in conjunction with USFWS at tide gate replacements in the Julia Butler Hanson National Wildlife Refuge. 4) McComas et al. Post-FCRPS Survival. Acoustic telemetry study using the JSATS (Juvenile Salmon Acoustic Telemetry System). As part of this project, Johnson will be evaluating juvenile salmon migration pathways in the estuary proper. Ebberts also explained the Portland District's involvement in restoration projects in the estuary at Fort Columbia, Julia Butler Hanson, Tenasillahe Island, and Crims Island.

\section{Estuary RME Document (11/30/06)}

Johnson described the status - the draft of May 2006 is the current version. He received comments from selected scientists (e.g., Giorgi, Hillman, Scranton, Thom). These comments, however, have not been incorporated into a new version. No changes have been made to the ERME document since May 2006. Tortorici wanted to make sure the ERME piece would be integrated into the new grand RME Plan when it gets traction again. Ebberts wondered why we needed to worry about the ERME document if the Action Agencies' Proposed Action was going to cover estuary RME. Tortorici replied that we still 
needed to see exactly what estuary RME in the Proposed Action would entail. Johnson added that the elements of the ERME document were used to develop the draft estuary RME for the Proposed Action, i.e., the latter is a subset of the former. Geiselman said the Proposed Action will contain specifics on who is committing to what regarding estuary RME, whereas the ERME document provides guidance as it stands now. Therefore, the ERME document is on hold pending the BiOp negotiations regarding RME and plans for a new, revised Grand RME Plan in 2007.

\section{Estuary Projects (11/30/06)}

At the request of the BPA, the EOS was asked to review three proposals concerning estuary RME currently in the solicitation process for the FY07-09 F\&W Program. These proposals received favorable reviews by the ISRP but the Council recommended "zero-funding" or "reduced-funding." BPA desired technical input from the EOS on the merits of the research because they have limited discretionary funds to spend on Endangered Species Act (ESA)-related projects. Johnson pointed out that EOS members had specific conflicts of interest for some of these proposals because members or their agencies were proposal sponsors (Tidal Freshwater Juvenile Salmon Ecology by PNNL et al.; Ecosystem Monitoring by Estuary Partnership et al.; Habitat Linkages by NOAA Fisheries et al.). As EOS facilitator, Johnson wanted this agenda topic to be a discussion between the Action Agencies (BPA and USACE) with the project sponsors available to answer clarifying questions. A lively discussion ensued. The BPA and USACE said they'd consider the information and decide on a course of action as part of the Proposed Action.

\subsubsection{Meeting Highlights - April 12, 2007}

Highlights of the meeting April 12, 2007 follow. The participants of the April 12, 2007 meeting included: Heida Diefenderfer and Gary Johnson (PNNL), Blaine Ebberts and Doug Putman (USACE), Scott McEwen (Estuary Partnership), Russell Scranton (NOAA Fisheries), and Tracey Yerxa (BPA). The meeting's objectives were to: 1) Introduce and organize the meeting, 2) Receive an update on federal RME for the new BiOp, 3) Review the Estuary Module for the Recovery Plan, 4) Discuss the Estuary RME document, 5) Decide what to do about forming a Columbia Estuary Coordinating Committee, 6) Receive an update on PNAMP monitoring inventory and the PNAMP Estuary Group, 7) Discuss the NED (Northwest Environmental Data network), 8) Discuss coordination for the estuary RME projects, 9) Advertise the Estuary Partnership/ U.S. Geological Survey (USGS) water quality conference, and 10) Set the next meeting date.

\section{Federal RME (4/12/07)}

Yerxa reported on the ongoing BiOp Collaboration effort. Final drafts of "raw level" RME for the Proposed Action (PA) have been developed. The PA is due to be released for public comment on 5/21/07. The new Biological Opinion is due to Judge Redden in summer 2007.

\section{Estuary Module (4/12/07)}

Scranton explained that the draft Estuary Module prepared by the Estuary Partnership is being reviewed by scientists at the NOAA Fisheries' Northwest Fisheries Science Center. NOAA Fisheries is 
examining density dependence, potential uses by different evolutionarily significant units (ESUs), benefits of pile dike removal for stream-type life histories, removal of predator habitat, and uncertainties. The Recovery Plan will actually have four modules: Estuary, Ocean, Harvest, and Hatchery. The Estuary Module includes the Estuary RME document by reference. See this website to download the Estuary Module is available for downloading at the following web site -- http://www.nwr.noaa.gov/SalmonRecovery-Planning/ESA-Recovery-Plans/Other-Documents.cfm.

\section{Estuary RME Document (4/12/07)}

Johnson noted that the status of the Estuary RME document had not changed - it was on hold pending release of the Proposed Action (PA). The EOS recognized the need to coordinate with RME upriver at the dams and tributaries. Scranton said that NOAA Fisheries will soon release their guidance for RME for recovery planning (NOAA Fisheries' official Adaptive Management for Salmon Recovery: Evaluation Framework and Monitoring -- now posted at http://www.nwr.noaa.gov/Salmon-Recovery-Planning/ESARecovery-Plans/Other-Documents.cfm). Yerxa cautioned that BPA is against funding status monitoring projects per se, although some status monitoring elements might be appropriate on a discretionary basis. Ebberts questioned why we needed a stand-alone Estuary RME document if the PA and Estuary Module will be including specific RME actions. Yerxa replied that the Estuary RME document is serving as the basis for estuary RME actions in both the PA and the Estuary Module. Scranton noted that the Estuary RME document and the RME elements of the Estuary Module need to be consistent. McEwen mentioned that the Lower Columbia Fish Recovery Board's work on Monitoring, Research, and Evaluation (MRE) is focused primarily on lower river tributary watersheds. There doesn't appear to be much overlap, if any, with the EOS's Estuary RME document. The EOS agreed that we need to update the current version based on comments from the internal reviewers and new materials, and then make this version of the Estuary RME document public. Yerxa reminded the group that Eric Braun of the USACE had some changes he wanted incorporated. ACTION ITEM: Johnson will compile works that will inform the update to the Estuary RME document, including the PA, the Recovery Plan, the Estuary Module, internal reviewer comments, and Braun's suggested changes.

\section{Coordinating Committee (4/12/07)}

Johnson solicited feedback from the EOS on whether or not to move forward with development of the Columbia Estuary Coordinating Committee. The purpose of the committee would be to coordinate habitat restoration and RME activities across all programs and parties in the estuary. Many of the EOS members participated in the inaugural exploratory meeting of the new committee. Yerxa and Ebberts pointed out that there would not likely be funding from the BPA and USACE, respectively. Diefenderfer asked about plans to roll-up the information. McEwen recommended that we not do the committee at this time but instead use existing forums, such as the EOS and the Estuary Partnership's Science Work Group, to improve coordination and facilitate roll-up of information. The EOS agreed.

\section{PNAMP (4/12/07)}

The PNAMP Estuary Group has been dormant since the RME Program/Project inventory was assigned elsewhere. Now that the inventory is finished, there may be a revival of this group. Scranton 
described some of the formal review comments he provided. Of importance, the estuary projects could not be viewed by users of the electronic inventory system because of a technical problem with the GIS layer. ACTION ITEM: Johnson will forward Scranton's comments to the EOS. It was agreed that there was no need for the EOS to provide further comments. Johnson informed the EOS that Curtis Roegner (NOAA Fisheries), representing the estuary restoration monitoring protocols developed under the Cumulative Effects project with Ebberts at the USACE, would be attending the PNAMP Protocols Manager meeting in May. Note, the Protocols Manager is a software program.

\section{NED (4/12/07)}

McEwen said the NED folks were recommending using the estuary as one of a few test "data portals" and that the Estuary partnership might be a "channel steward." None of this has been approved or finalized. For more information, see http://www.nwcouncil.org/ned/. The Regional Information Management Strategy (RIMS) is going to be subsumed into NED. As Jim Geiselman wrote in an email to interested parties on 12/12/06, "FYI - As discussed at the Collaboration RM\&E workgroup meeting on November 27, and consistent with our agreements to use existing processes and products, an information management strategy for Columbia Basin anadromous salmonid population and habitat data is being coordinated through NED and PNAMP. This information management strategy will be coordinated with the Collaboration RM\&E workgroup as it develops further for consideration in the data management sections of the draft Proposed Action and the RM\&E Collaboration Framework as appropriate."

\section{Estuary RME Project Coordination (4/12/07)}

The EOS briefly discussed the estuary RME projects that were receiving funding in 2007. ACTION ITEM: Ebberts and Yerxa to arrange a coordination meeting of the principle investigators, BPA, Corps, NOAA Fisheries, etc. Diefenderfer asked about technical reports from previous work on the estuary RME projects. Ebberts replied that he was pushing for them. In addition, Ebberts asked that we add the USFWS monitoring project at the Julia Butler Hanson National Wildlife Refuge to the EOS's estuary RME project list.

\section{Water Quality Conference (4/12/07)}

The Estuary Partnership and the USGS will be convening a conference on May 7-9, "Many Perspectives, One River," in Vancouver, WA. Many EOS members planned to attend.

\subsubsection{Meeting Highlights - July 11, 2007}

Highlights of the meeting July 11, 2007 follow. The participants included: Heida Diefenderfer (phone) and Gary Johnson (PNNL), Blaine Ebberts and Doug Putman (USACE), Scott McEwen and Leyla Arsan (Estuary Partnership), Russell Scranton (NOAA Fisheries), and Jim Geiselman (phone) and Tracey Yerxa (BPA). The purpose of the meeting was to coordinate and update activities pertaining to estuary RME. McEwen introduced Leyla Arsan, the new monitoring coordinator for the Estuary Partnership. 


\section{Previous Meeting Notes (7/11/07)}

There were no comments on the draft notes from the previous meeting. The EOS went over the action items. Several remain to be completed. ACTION ITEM: Ebberts and Yerxa to discuss convening a meeting of USACE and BPA researchers to coordinate among complementary research activities.

ACTION ITEM: Johnson will provide the EOS a) a package via email with the comments from internal reviews (Giorgi, Hillman, etc.) of the May 2006 ERME document, and b) links to the Proposed Action, the Estuary Module, etc. (as follows).

- Proposed Action http://www.salmonrecovery.gov/biological_Opinions/FCRPS/ biop_remand_2004/

- Estuary Module http://www.nwr.noaa.gov/Salmon-Recovery-Planning/ESA-RecoveryPlans/Other-Documents.cfm

- Adaptive Management for Salmon Recovery: Evaluation Framework and Monitoring http://www.nwr.noaa.gov/Salmon-Recovery-Planning/ESA-Recovery-Plans/OtherDocuments.cfm

\section{Federal RME (7/11/07)}

The draft Proposed Action as part of the BiOp remand process was issued on May 21, 2007. Geiselman reported that the Action Agencies are working on "concreting" the proposed actions. They will be receiving comments from NOAA Fisheries on the performance standards and adaptive management pieces, among others. He did not know of any contentious issues for the estuary. The final Proposed Action is scheduled to be released in mid-August 2007. The new FCRPS BiOp from NOAA Fisheries is scheduled to be released by the end of October 2007. Yerxa added that Braun from the USACE North Pacific Division office wants to assess the performance measures in the estuary. She also said that NOAA Fisheries has not had any major comments on the estuary RME elements of the Proposed Action, other than to say they want compliance monitoring and some action effectiveness research and status and trend monitoring.

Geiselman noted the material on tributary RME in the Proposed Action contained new state-of-thescience on RME that the EOS should consider. He explained that status and trend monitoring is now integrated with action effectiveness research in the latest RME thinking. ACTION ITEM: Before our next meeting, EOS to review tributary RME (PDF pages 72-105 in the RME chapter in the Proposed Action). Scranton noted that NOAA Fisheries was working to coordinate between the Recovery Planning and BiOp Remand efforts within NOAA Fisheries.

Yerxa brought up the concept of an "expert panel" to review the benefits and outcomes of BPAfunded habitat restoration actions. She explained that this group, which is still in the idea stage, would incorporate the latest research findings into their assessments. Ebberts commented that he wants the EOS to remember the context of salmon recovery. 
According to Geiselman, there are no plans at this time to revive the grand RME document. An Executive Summit meeting is scheduled for October 2007. Topics to be discussed include data management, monitoring requirements, strategies to obtain monitoring data, and regional strategies to integrate monitoring results.

The EOS decided to update the ERME document based on comments received in May 2006. Geiselman asked if PNAMP's proposed demonstration project would be included. Scranton and McEwen didn't think it would be appropriate because the demonstration project is apparently focused on lower Columbia watersheds, not the mainstem. ACTION ITEM: Johnson and Diefenderfer to draft a new version of the ERME document and send it to the EOS by September 30, 2007.

\section{PNAMP (7/11/07)}

The PNAMP Estuary Group will be meeting on July 18, 2007. Since many EOS members will be participating in this meeting, we discussed several pertinent activities. Scranton reported the PNAMP data dictionary, a collection of definitions and metrics for various monitored indicators, is being drafted and will be presented at the July 18 meeting. He mentioned that the Habitat Restoration Effectiveness Monitoring Protocols for the Estuary developed by the USACE (Roegner et al. 2007) will be incorporated into the data dictionary. Diefenderfer noted that Craig Cornu at the South Slough National Estuarine Research Reserve is doing a review of monitored indicators on restoration projects in conjunction with the NOAA Restoration Center. Scranton said he will coordinate with Cornu. Geiselman said PNAMP should have two work products out soon: a) Information Needs and Management Questions and b) Outline of Monitoring Network and Parallel Strategy for Data Management.

\section{Pile Structures (7/11/07)}

McEwen explained that only so much can be done to re-establish connections between the mainstem and the floodplain because of private lands, infrastructure, etc. But, there are habitat restoration opportunities to pursue regarding pile structures. In some locations, piles act as barriers, in others they are obstructions. He noted the Northwest Fisheries Science Center (NOAA Fisheries) is concerned about piles as predator habitats. There are potential benefits for connectivity, passage, and predation to removing pile structures, but there are also definite uncertainties. The Estuary Partnership received a $\$ 100 \mathrm{~K}$ grant from the NOAA Restoration Center to remove piles at Cole Creek Slough. This will be a demonstration project. USGS is responsible for the monitoring of this project. McEwen also mentioned that BPA intends to fund estuary habitat restoration specifically directed at pile structure removal. Putman described the USACE's plan concerning pile structure as part of the Columbia Estuary General Investigations Study. He said they are going to fund a broad-scale research effort to characterize pile structure biologically, physically, and hydraulically in order to assess advantages and disadvantages of their removal. The USACE wants to develop a programmatic methodology and a scientific basis to prioritize their actions. Johnson asked if there was a mechanism yet to coordinate among the various entities involved in pile structure planning, research, monitoring, and assessment. McEwen replied that they were hoping to establish a work group to share results and coordinate activities.

\section{Estuary Module (7/11/07)}


McEwen reported the draft Estuary Module for the Lower Columbia/Willamette Recovery Plan produced by the Estuary Partnership under contract to NOAA Fisheries has been reviewed internally and is scheduled to be submitted to the Federal Register in August for public comment. While this review is occurring, NOAA Fisheries intends to have the Estuary Partnership work with Battelle and Trask and Associates to incorporate estuary RME into the module. This would be a direct application of the EOS's ERME work. Putman asked if the monitoring activities that are required for the module, but aren't currently in the ERME document and hence will need to be developed, will eventually be fed back and incorporated into the ERME. Johnson replied that we do not know at this time. Ebberts noted that there will be lots of uncertainty with the management action in the module. ACTION ITEM: Johnson will share with the EOS the scope of work for Battelle's involvement in RME for the Estuary Module.

\section{Estuary RME Projects (7/11/07)}

Ebberts reported that the Cumulative Effects project had a draft report for 2006 out for review and the project's work products were getting traction outside the Columbia, e.g., in Puget Sound. Johnson reported on the Tidal Freshwater Monitoring project in the vicinity of the Sandy River delta. Beach seine and acoustic telemetry sampling started in May and June, 2007. Monthly beach seine efforts will continue for a year, at which time the sampling design will be re-assessed. Other projects will be visited in future EOS meetings.

\section{NED (7/11/07)}

Geiselman provided an update on NED, the Northwest Environmental Data network. The NED group is working on planning for the Executive Summit and developing a strategy document. A subgroup of NED is working on management of information coming out of the Northwest Power and Conservation Council's Fish and Wildlife Program. NED will eventually focus on broad regional management needs. Scranton, who participates in NED, added that they are pursuing a Memorandum of Understanding and a document on best practices for data management. McEwen gave an update on the estuary as a pilot data portal for NED. The Estuary Partnership might become a channel steward for an estuary data portal. Nothing has been decided yet. Such an effort would require a long-term funding commitment.

\section{CSMEP (7/11/07)}

CSMEP stands for the Collaborative Systemwide Monitoring and Evaluation Program. It is managed by the Columbia Basin Fish and Wildlife Authority. Yerxa explained that CSMEP, in part, provides technical support to the fish monitoring component of PNAMP. CSMEP does not have an estuary element.

\subsubsection{Estuary Data Management}

This FY07 objective was in stand-by mode pending outcome of the regional data management initiative called the Northwest Environmental Data-Network (NED). NED will support the data management needs of PNAMP. NED's mission will involve regional data integration. NED will work to 
discover the data gaps, how best to share data, and to determine the quality of the data. In FY07, the EOS kept abreast of this data management effort, but did not perform any estuary data management activities.

\subsubsection{Estuary RME Conference}

During FY07, the EOS did not perform any activities related to the Estuary RME Conference because 2007 was an off-year between biennial events. Previously, the EOS facilitated and participated in an estuary RME conference in Astoria, Oregon, on April 19-20, 2006. The event was called the Conference on Research, Monitoring, and Restoration in the Lower Columbia River, Estuary, and Nearshore Ocean. The proceedings (Johnson and Sutherland 2006) include copies of the presentations, abstracts, speaker biographies, and notes on the question/answer sessions. A conference is scheduled for spring 2008.

\subsubsection{PNAMP Estuary Workgroup}

The PNAMP estuary workgroup, which formed in FY05, was a minor activity for Project 2002-07700 resources in FY07 because the PNAMP estuary workgroup apparently did not meet during FY07. Overall, a main focus of the PNAMP effort in FY07 pertinent to estuary RME was the project and program inventory. This inventory was conducted by the Pacific States Marine Fisheries Commission.

\subsection{Work Element 119 - Manage and Administer Project}

\subsubsection{PISCES Format}

BPA rolled out PISCES in FY05 and continued supporting this project tracking system during FY06 and FY07. Accordingly, Johnson continued to provide input on Project 2002-077-00 to PISCES.

\subsubsection{FY08 Scope of Work and Budget}

PNNL developed and submitted the FY08 scope of work and budget for Project 2002-077-00 to BPA via PISCES in August 2007. Project work in FY08 will involve EOS, estuary PNAMP, and revisions to the RME plan.

\subsection{Work Element 132 - Annual Report}

\subsubsection{Annual Report}

The document herein fulfills the annual report objective.

\subsubsection{Biennial Estuary RME Report}

The EOS proposed the idea for a biennial report on RME work in the Columbia River Estuary in their Estuary RME Plan (Johnson et al. 2004). Accordingly, the BPA included development of an outline for such a report as an objective in Project 2002-077-00 during FY05 and FY06. However, the EOS did not 
work on this topic in FY07. The purpose of the biennial report would be to summarize, synthesize, and evaluate new findings in the context of the major management questions. The biennial report would be a key part of the adaptive management process for RME in the Columbia River estuary. A draft outline follows (adapted and expanded from the FY06 Annual Report, Johnson 2006).

Title: Research, Monitoring, and Evaluation in the Columbia River Estuary: Biennial Report Front-of-the-Book

Title page

Disclaimer page

Executive Summary

Preface

Table of Contents

List of Figures

List of Tables

Acronyms

Glossary

Chapter 1 - Introduction [why, when, where]

Purpose

Background

Study Area

Contents

Chapter 2 - Management Needs [what the RME work is intended to address, i.e., the drivers for the research and monitoring]

Introduction

Federal Estuary Program Goal and Objectives

Key federal management questions [link to Estuary RME Proposed Action]

Federal RME Objectives [link to Estuary RME Plan]

Chapter 3 - Research and Monitoring [describe what's being done to address management needs]

Introduction

Federal Agencies, Programs, and Funding Processes [Corps, BPA, through LCREP, other]

Categories: Status \& trends, Action effectiveness, Uncertainties research

Performance Indicators and Monitored Attributes [link to Estuary RME Plan]

Project Descriptions [objectives, methods (briefly), and types of data]

Gap Analysis [relative to RME Plan and EORME Proposed Action]

Summary

Chapter 4 - Synthesis of Major Findings [tie all agency/program RME results together] 
Introduction

Major Findings [include published and unpublished results to extent possible]

Synthesis

Chapter 5 - Assessment [gap analysis, i.e., how well is the RME meeting management needs]

Introduction

Implications of RME findings for federal project design

Implications of RME findings for federal program development \& management

Evaluation of Information Dissemination/Sharing/Management

Gap Analysis

Adaptive Management Needs [summary of how RME findings in the report should affect federal estuary program and project actions]

Chapter 6 - Conclusions and Recommendations

Chapter 7 -- References

\subsection{Work Element 141 - Status Reports}

Status reports on Project 220-077-00 were submitted quarterly by PNNL to BPA in FY07 by G. Johnson. They describe the activities and accomplishments for a given month and planned activities for the next month. In FY08, project status reports will continue to be produced quarterly.

\subsection{Work Element 174 - Produce Plan}

This work element pertains to the federal Estuary RME Plan that was released for internal review in September 2007 (Johnson et al. 2007). During FY05 and FY06, we received comments from numerous reviewers, including the Independent Scientific Review Panel (ISRP). The reviewers generally supported the ecosystem-basis, structure, and content of the Estuary RME Plan. Some of their major concerns, however, included unclear programmatic goals, inconsistent and sometimes unmeasurable objectives, weak development and application of the conceptual ecosystem model, ineffectual performance indicators, lack of prioritization of monitored attributes, under-developed sampling designs, and no apparent standard monitoring protocols. Furthermore, the Plan's section containing the actions recommended to implement the Plan needed more specifics. For example, exactly how would the adaptive management process work and who would be in charge? Based on review comments, we worked to revise the federal Estuary RME Plan during 2007. The FY07 revisions were substantial and reflect developments in the Estuary and Ocean Research, Monitoring and Evaluation Proposed Action. The FY07 draft revised federal Estuary RME Plan (Johnson et al. 2007) was delivered to BPA in September 2007. 


\subsection{Accomplishments and Recommendations}

In conclusion, accomplishments during FY07 from Project 2002-077-00 were as follows:

- Continued facilitation and coordination of the EOS as it worked to respond to reviewer comments on the federal Estuary RME Plan, initiated implementation of the Plan, and provided input to the federal RME effort.

- Tracked RME efforts related to Federal RME in the estuary (e.g., NED, CSMEP, Estuary Module, PNAMP, tributary RME, conferences and meetings, estuary restoration projects, and research and monitoring).

- Contributed to PNAMP's estuary inventory effort by helping develop the inventory for monitoring programs and projects from Northern California to Puget Sound.

- Refreshed data on Project 2002-077-00 in BPA's project tracking system, PISCES.

- Submitted quarterly status report describing project activities, accomplishment, and planned tasks.

- Delivered a revised draft federal Estuary RME Plan to BPA (September 2007) addressing reviewer comments and updates in the Estuary and Ocean Research, Monitoring and Evaluation Proposed Action.

For FY08, the following recommendations for activities for Project 2002-077-00 are organized by work elements:

118 Coordination -- Continue facilitation of the estuary/ocean RME subgroup, including coordination with:

- Federal RME - attend meetings and provide status reports as required;

- PNAMP Estuary Workgroup - attend and participate in workgroup meetings and assist in the development of coordinated estuary planning and monitoring approaches within PNAMP;

- CSMEP - inform CSMEP about estuary RME activities and coordinate as necessary;

- RME Data Management Subgroup -- coordinate the estuary RME work with the developing data management effort for the basin-wide RME;

- NPCC and UPA -- convene biennial estuary RME workshops to present new data, evaluate the conduct of the estuary RME program, exchange information, and provide input to the estuary/ocean RME subgroup. 
119 Project Management -- Manage and administer the project according to BPA's "Work Element/Milestone" based project management and reporting system (PISCES).

132 Annual Report -- Produce an annual report of project activities, including a detailed outline for a biennial estuary RME summary report incorporating adaptive management recommendations at the program level for submittal to the Action Agencies, estuary restoration project leaders, and other related entities (e.g., subbasin planners, PNAMP).

141 Status Reports -- Produce quarterly status reports.

174 Plan -- Revise the estuary-RME plan (dated September 2007) as necessary as new information becomes available concerning RME in the Columbia River estuary. 


\subsection{Literature Cited}

Berquam, T.B., B.D. Ebberts, and J. Wilcox. 2003. Action Plan to Implement the FCRPS Biological Opinion in the Columbia River Estuary. Submitted to NOAA Fisheries, Portland, Oregon. September 30, 2003.

Bottom, D. L., K. K. Jones, and J. J. Herring. 1984. Fishes of the Columbia River Estuary. Internal report, 113, P. Available from Columbia River Data Development Program, Astoria OR. (Managed by Columbia River Estuary Taskforce, www.columbiaestuary.org.)

Bottom, D.L., C.A. Simenstad, J. Burke, A.M. Baptista, D.A. Jay, K.K. Jones, E. Casillas, and M.H. Schiewe. 2005. Salmon at River's End: The Role of the Estuary in the Decline and Recovery of Columbia River Salmon. NOAA Technical Memorandum NOAA Fisheries-NWFSC-68. Northwest Fisheries Science Center, Seattle, Washington.

Columbia River Estuary Data Development Program (CREDDP). 1984a. Index to CREDDP Data. Compiled by H.T. Mercier. S. Bell, ed. Columbia River Estuary Study Taskforce, Astoria, Oregon.

Columbia River Estuary Data Development Program (CREDDP). 1984b. Abstracts of Major CREDDP Publications. Compiled by D. Fox. Columbia River Estuary Study Taskforce, Astoria, Oregon.

Dawley, E.M., R.D. Ledgerwood, and A.L. Jensen. 1985a. Beach and Purse Seine Sampling of Juvenile Salmonids in the Columbia River Estuary and Ocean Plume, 1977-1983; Volume I; Procedures, Sampling Effort and Catch Data. U.S. Dep. Commerce, NOAA Tech. Memo. NOAA Fisheries, F/NWC-74:1-260.

Dawley, E.M., R.D. Ledgerwood, and A.L. Jensen. 1985b. Beach and Purse Seine Sampling of Juvenile Salmonids in the Columbia River Estuary and Ocean Plume, 1977-1983; Volume II; Data on Marked Fish Recoveries. U.S. Dep. Commerce, NOAA Tech. Memo. NOAA Fisheries, F/NWC-75:1-397.

Dawley, E.M., R.D. Ledgerwood, T.H. Blahm, C.W. Sims, J.T. Durkin, R.A. Kirn, A.E. Rankis, G.E. Monan, and F.J. Ossiander. 1986. Migrational Characteristics, Biological Observations, and Relative Survival of Juvenile Salmonids Entering the Columbia River Estuary, 1966-1983. Report to Bonneville Power Admin., Portland, Oregon. Contract DACW57-85-F-0623, 256 p.

Durkin, J.T., T. Blahm; G. McCabe, T. Coley, R. McConnell, R. Emmett, and W. Muir. 1981. Columbia River Estuary Data Development Program Report: Salmonid and Non-Salmonid Fish. Study managed by Columbia River Estuary Study Taskforce for the Pacific Northwest River Basins Commission, Vancouver, Washington. 146 pages.

Dyer, K.R. and R.J. Orth, eds. 1994. Changes in Fluxes in Estuaries: Implications from Science to Management. Proceedings of ECSA22/ERF Symposium, 13-18September 1992, Institute of Marine Studies, University of Plymouth. Olsen \& Olsen, Fredensborg.

Fresh, K.L., E. Casillas, L.L. Johnson and D.L. Bottom. 2004. Role of the Estuary in the Recovery of Columbia River Basin Salmon and Steelhead: an Evaluation of Selected Factors on Population Viability. NOAA Technical Memorandum, Northwest Fisheries Science Center, National Marine 
Fisheries Service, NOAA, Seattle, WA, May 2004.

Fuhrer, G.J., D.Q. Tanner, J.L. Morace, S.W. McKenzie and K.A. Skach. 1996. Water Quality of the Lower Columbia River Basin: Analysis of Current and Historical Water-Quality Data through 1994. U.S. Geological Survey Water-Resources Investigations Report 95-4294, prepared in cooperation with the Lower Columbia River Bi-State Water-Quality Program, Portland, Oregon. Available URL: www.lcrep.org

Johnson, G. 2006. Facilitation of the Estuary/Ocean Subgroup for Research, Monitoring, and Evaluation, FY06 Annual Report. PNNL-16142. Report submitted to the Bonneville Power Administration, Portland, Oregon, by the Pacific Northwest National Laboratory, Richland, Washington.

Johnson, G. 2005. Estuary/Ocean Research, Monitoring, and Evaluation Support Project: FY05 Annual Report. Report submitted to the Bonneville Power Administration, Portland, Oregon, by the Pacific Northwest National Laboratory, Richland, Washington.

Johnson, G. and B. Sutherland (eds.). 2006. Conference on Research, Monitoring, and Restoration in the Lower Columbia River, Estuary, and Nearshore Ocean. Proceedings from a conference in Astoria, Oregon on April 19-20, 2006. Available at http://cerc2006.pnl.gov/.

Johnson, G., H. Diefenderfer, B. Ebberts, C. Tortorici, T. Yerxa, S. McEwen, J. Leary, and J. Skalski. 2006. Federal Columbia River Estuary Research Monitoring and Evaluation Program. Bonneville Power Administration. Portland, Oregon. May 2006.

Johnson, G., H. Diefenderfer, B. Ebberts, C. Tortorici, T. Yerxa, J. Leary, and J. Skalski. 2007. Federal Columbia River Estuary Research Monitoring and Evaluation Program. Bonneville Power Administration. Portland, Oregon. September 2007.

Johnson, G., H. Diefenderfer, T. Berquam, B. Ebberts, C. Tortorici, and J. Wilcox. 2004. Plan for Research Monitoring and Evaluation of Salmon in the Columbia River Estuary. Final draft submitted August 10, 2004, to the Bonneville Power Administration, Portland, Oregon, by the Pacific Northwest National Laboratory, Richland, Washington.

Johnson, G. and seven co-authors. 2003. An Ecosystem-Based Approach to Habitat Restoration Projects with Emphasis on Salmonids in the Columbia River Estuary. PNNL-14412, Final report submitted to the Bonneville Power Administration, Portland, Oregon, by the Pacific Northwest National Laboratory, Richland, Washington.

Jordan, C., J. Geiselman, M. Newsom, and J. Athearn (eds.). 2003. Research, Monitoring \& Evaluation Plan for the NOAA-Fisheries 2000 Federal Columbia River Power System Biological Opinion. Draft dated September 11, 2003. NOAA Fisheries, Bonneville Power Administration, U.S. Army Corps of Engineers, and Bureau of Reclamation.

Kirn, R.A., R.D. Ledgerwood, and A.L. Jensen. 1986. Diet of Subyearling Chinook Salmon (Oncorhynchus tshawytscha) in the Columbia River Estuary and Changes Effected by the 1980 Eruption of Mount St. Helens. Northwest Science 60: 191-196.

Ledgerwood, R.D., F.P. Thrower, and E.M. Dawley. 1991. Diel sampling of migratory juvenile 
salmonids in the Columbia River estuary. Fisheries Bulletin 89: 69-78.

Lower Columbia River Estuary Partnership and Lower Columbia Fish Recovery Board. 2004a. Lower Columbia Salmon and Steelhead Recovery and Subbasin Plan. Volume I and II. Draft report prepared for the Northwest Power and Conservation Council, May 28, 2004. Available URL: http://www.nwcouncil.org/fw/subbasinplanning/lowerColumbia/plan/.

Lower Columbia River Estuary Partnership and Lower Columbia Fish Recovery Board. 2004b. Supplement to the Mainstem Lower Columbia River and Columbia River Estuary Subbasin Plan. Prepared for the Northwest Power and Conservation Council, November 22, 2004. Available URL: http://www.lcrep.org/pdfs

Lower Columbia River Estuary Program (now called Partnership). 1999. Lower Columbia River Estuary Plan, Comprehensive Conservation and Management Plan. Volume I, Portland, Oregon.

McCabe, G.T. Jr., R.L. Emmett, W.D. Muir, and T.H. Blahm. 1986. Utilization of the Columbia River Estuary by Subyearling Chinook Salmon. Northwest Science, Vol. 60, No. 2, pp.113-124.

McCabe, G.T. Jr., W.D. Muir, and J. T. Durkin. 1983. Interrelationships between juvenile salmonids and nonsalmonid fish in the Columbia River Estuary. U.S. Bur. Fish. Bull. 81: 815-826.

McConnell, R., T Blahm, G. Jr McCabe, T. Clocksin, T. Coley, J. Durkin, R. Emmett, and W. Muir. 1983. Columbia River Estuary Data Development Program Data Report: Salmonid and NonSalmonid Fish, four volumes. Columbia River Estuary Data Development Program. Managed by Columbia River Estuary Taskforce, Astoria, Oregon.

NMFS (National Marine Fisheries Service, now called NOAA Fisheries). 2000. Federal Columbia River Power System Biological Opinion: Reinitiation of Consultation on Operation of the Federal Columbia River Power System, Including the Juvenile Fish Transportation Program, and 19 Bureau of Reclamation Projects in the Columbia Basin. NMFS-NWR, Seattle, Washington. December 2000.

NMFS. 2004. Biological Opinion on Operation of the Federal Columbia River Power System. Available at http://www.salmonrecovery.gov/ implementation.

Pacific Northwest Aquatic Monitoring Partnership (PNAMP). 2004. Recommendations for Coordinating State, Federal, and Tribal Watershed and Salmon Monitoring Programs in the Pacific Northwest. Draft. Portland, Oregon. January 6, 2004.

Pruter, A.T. and D.L. Alverson (eds.). 1972. The Columbia River Estuary and Adjacent Ocean Waters: Bioenvironmental Studies. University of Washington Press, Seattle, Washington.

Reimers, P.E., and R.E. Loeffel. 1967. The length of Residence of Juvenile Fall Chinook Salmon in Selected Columbia River Tributaries. Res. Briefs, Fish Comm. Oreg. 13(1): 5-19

Rich, Willis H. 1920. Early history and seaward migration of Chinook salmon in the Columbia and Sacramento rivers. U.S. Bur. Fish. Bull. 37: 2-73.

Roegner, G.C., H. Diefenderfer, A. Whiting, A. Borde, and R. Thom. 2006. Protocols Manual for Action Effectiveness Research in the Columbia River Estuary. Submitted to U.S. Army Corps of Engineers, Portland District. 
Small, L.F. (ed.). 1990. Columbia River: Estuarine System. Progress in Oceanography vol. 25, no. 1-4.

TetraTech. 1996. The Health of the River 1990-1996: integrated technical report. Report TC 0253-01, prepared by Tetra Tech for the Lower Columbia River Bi-State Program, May 20, 1996. Available URL: www.lcrep.org.

U.S. Army Corps of Engineers (USACE). 2001. Biological Assessment Columbia River Channel Improvements Project. Submitted to NOAA Fisheries and USFWS. December 28, 2001. Portland, Oregon. 